\title{
Effect of a UK Pay-for-Performance Pro- gram on Ethnic Disparities in Diabetes Outcomes: Interrupted Time Series Analysis
}

Riyadb Alshamsan, MSc

Jobn Tayu Lee, MSc

Azeem Majeed, MD

Gopalakrishnan Netuveli, PbD

Christopher Millett, PbD

Department of Primary Care and Public Health, Imperial College, London, United Kingdom

각

MORE ONLINE

www.annfammed.org
Conflicts of interest: authors report none.

\section{CORRESPONDING AUTHOR}

Riyadh Alshamsan, MSc

Department of Primary Care and Public

Health

The Reynolds Bldg

St Dunstan's Rd

W6 8RP

London, United Kingdom

ra105@imperial.ac.uk

\begin{abstract}
PURPOSE We wanted to examine the long-term effects of the Quality and Outcomes Framework (QOF), a major pay-for-performance program in the United Kingdom, on ethnic disparities in diabetes outcomes.

METHODS We undertook an interrupted time series analysis of electronic medical record data of diabetes patients registered with 29 family practices in South West London, United Kingdom. Main outcome measures were mean hemoglobin $A_{1 c}\left(H_{b A_{1 c}}\right)$, total cholesterol, and blood pressure.

RESULTS The introduction of QOF was associated with initial accelerated improvements in systolic blood pressure in white and black patients, but these improvements were sustained only in black patients (annual decrease: $-1.68 \mathrm{~mm}$ $\mathrm{Hg} ; 95 \% \mathrm{Cl},-2.41$ to $-0.95 \mathrm{~mm} \mathrm{Hg}$ ). Initial improvements in diastolic blood pressure in white patients $(-1.01 \mathrm{~mm} \mathrm{Hg} ; 95 \% \mathrm{Cl},-1.79$ to $-0.24 \mathrm{~mm} \mathrm{Hg})$ and in cholesterol in white $(-0.13 \mathrm{mmol} / \mathrm{L} ; 95 \% \mathrm{Cl},-0.21$ to $-0.05 \mathrm{mmol} / \mathrm{L})$ and black $(-0.10 \mathrm{mmol} / \mathrm{L} ; 95 \% \mathrm{Cl},-0.20$ to $-0.01 \mathrm{mmol} / \mathrm{L})$ patients were not sustained in the post-QOF period. There was no beneficial impact of QOF on $\mathrm{HbA}_{1 \mathrm{c}}$ in any ethnic group. Existing disparities in risk factor control remained largely intact (for example; mean $\mathrm{HbA}_{1 \mathrm{c}}$ : white $7.5 \%$, black $7.8 \%$, south Asian $7.8 \%$; $P<.05$ ) at the end of the study period.
\end{abstract}

CONCLUSION A universal pay-for-performance scheme did not appear to address important disparities in chronic disease management over time. Targeted quality improvement strategies may be required to improve health care in vulnerable populations.

Ann Fam Med 2012;10:228-234. doi:10.1370/afm.1335.

\section{INTRODUCTION}

7 he Quality and Outcomes Framework (QOF) is a pay-for-performance program that is unique in its scope and cost. It rewards family practitioners in the United Kingdom for the achievement of predetermined targets and represents approximately up to $25 \%$ of a practice income. The scheme is divided into domains that cover clinical, patient experience, and organizational aspects of care through which practices can earn up to 1,000 points, with each point generating on average a payment of $\$ 200$ (£124). Diabetes accounts for approximately $15 \%$ of the QOF clinical domain points (650 points are available in the clinical domain). Currently one-half of the points available for diabetes care are directed toward the achievement of intermediate outcome targets, such as the control of blood pressure, cholesterol and hemoglobin $\mathrm{A}_{1 \mathrm{c}}\left(\mathrm{HbA}_{\mathrm{ic}}\right)$.

The impact of quality improvement strategies, such as pay-for-performance programs, on disparities in health care is an emerging area of research inquiry. ${ }^{1-3}$ Preliminary studies suggest that the impact of QOF on disparities in care has been mixed. Although there is some evidence that 
the management of chronic conditions in poorer areas has improved more rapidly after the introduction of QOF, disparities in care among age, sex, and ethnic groups appears to have largely persisted and in some disease areas worsened. ${ }^{4,5}$

The inverse equity hypothesis proposes that health interventions may initially benefit people of higher socioeconomic status (SES) and only later benefit lower SES groups, thus increasing disparities in the short term. ${ }^{6}$ This hypothesis is based on findings from child health studies in Brazil, however, and remains largely untested in populations with chronic illnesses in developed countries. Examining whether universal quality improvement programs, such as the QOF, address disparities in health care over time has important implications for policy makers and health planners. Research findings will inform decisions about whether additional resources are required for targeted interventions to improve care in vulnerable populations. Although the QOF was not explicitly designed to narrow disparities, associated systematic improvement and standardization in the quality of care may be expected to lead to reductions in disparities. ${ }^{7}$ For this reason, the UK Department of Health has stated that the QOF is likely to reduce disparities. ${ }^{8}$ In addition, the World Health Organization commission on social determinants of health has recommended that all new policies be evaluated for their impact on health disparities. ${ }^{9}$ We have previously shown that the introduction of QOF was associated with an initial widening of disparities in blood pressure control between white and black patients with diabetes. ${ }^{10} \mathrm{We}$ extend this work by using an interrupted time series analysis to test the inverse equity hypothesis, ie, that the QOF will attenuate these disparities over time.

\section{METHODS}

\section{Study Setting}

The study was conducted in Wandsworth, in southwest London, where the population is younger than that of England as a whole, with $74 \%$ aged less than 45 years (compared with a national average of $60 \%$ ), and with a high proportion of residents from ethnic minority groups: $8.8 \%$ are black and $4.4 \%$ are South Asian. All adult patients (18 years and older) with diabetes registered during 2007 in 29 of the 34 practices in the study area were included. Patients were identified by searching diagnostic and management Read codes in the patient electronic record using an established methodology. ${ }^{11}$ Read codes are the clinical classification system used in primary care in the United Kingdom. ${ }^{12}$ Historical clinical data were extracted on each patient for the years 2000 to 2007 from his or her electronic record.

\section{Variables}

Our outcome measures were mean blood pressure, total cholesterol, and $\mathrm{HbA}_{1 \mathrm{c}}$ based on each patient's last recorded measurement in each year. Our main predictor variable was ethnicity. Information on ethnic background is collected from the patient during consultation or upon registration and is entered in the patient's electronic record. Covariates in our analysis included age, sex, duration of diabetes, number of comorbid medical conditions, and neighborhood SES. Duration of diabetes was calculated in years using the date of diabetes diagnosis entered in the electronic medical record. Comorbid conditions included hypertension, stroke, atrial fibrillation, heart failure, coronary heart disease, asthma, chronic obstructive pulmonary disease, chronic kidney disease, and depression. We used practice postal codes to assign a neighborhood SES to each patient using the Index of Multiple Deprivation. ${ }^{13}$ The index is used to measure area-level SES in the United Kingdom and is composed of several dimensions, such as income, living environment, and unemployment. Nationally, the Index of Multiple Deprivation scores range from 0.37 (least deprived borough) to 85.46 (most deprived borough).

\section{Analysis}

To estimate changes in risk factor control associated with the QOF while controlling for secular trend, we fitted a segmented regression model of our time series for all the population and for the 3 ethnic groups. ${ }^{14,15}$ Ethnic groups included in our analysis were white, black, and South Asian. The model estimates 3 main parameters. The first parameter estimates the change in our outcome associated with each year before QOF was introduced in April 2004, the second parameter estimates the immediate change associated with QOF, and the third parameter estimates the change in our outcome associated with each year after QOF had been introduced. For each outcome, we treated patients and practices as random intercepts in a multilevel model to adjust for the correlation in error term within both individual level and practice level. Further, we estimated overall trends in disparities in risk factor control during the study period by including time as a continuous variable to represent each year and ranging from 1 (for the year 2000) to 8 (for the year 2007), with ethnicity as a predictor variable and the white group as the reference group. Additionally, to examine the extent of disparities at the end of the study period, we compared ethnic group differences in 2003 (the year before QOF) and 2007 using a linear regression model while adjusting for age, sex, SES, number of comorbidities, and practice-level clustering. We tested for attrition bias using Heckman selection models. ${ }^{16}$ 
The study was approved by the Wandsworth Local Research Ethics Committee. We performed all analysis using Stata 10.1 (Stata Corp LP).

\section{RESULTS}

We identified 7,434 diabetic patients registered with the practices in 2007. The mean age of patients was 59.1 years and $49.6 \%$ were female. Ethnicity was coded for $90.0 \%$ of patients: white patients comprised $47.5 \%$ of the sample, $27.1 \%$ were black, and $24.7 \%$ were South Asian (Table 1).

\section{$\mathrm{HbA}_{1 \mathrm{c}}$}

The mean $\mathrm{HbA}_{1 \mathrm{c}}$ level was decreasing in all 3 ethnic groups before introduction of the QOF program $(P<.01)$. In its initial year, $Q O F$ was associated with a significant increase in mean $\mathrm{HbA}_{1 \mathrm{c}}$ among South Asian patients $(0.18 \% ; 95 \% \mathrm{CI}, 0.02 \%$ to $0.34 \%)$, but not in the other groups. During the next 3 years, however, $\mathrm{HbA}_{1 \mathrm{c}}$ levels increased significantly in each ethnic group relative to the pre-QOF trend (Table 2 and Figure 1).

\section{Cholesterol}

Mean total cholesterol level was decreasing in all 3 ethnic groups before introduction of the QOF program

\section{Table 1. Patient Characteristics in 2007}

\begin{tabular}{|c|c|c|c|c|}
\hline Characteristic & $\begin{array}{l}\text { All Patients } \\
(\mathrm{N}=7,434)\end{array}$ & $\begin{array}{c}\text { White } \\
(n=3,181)\end{array}$ & $\begin{array}{c}\text { Black } \\
\text { (n }=1,811)\end{array}$ & $\begin{array}{c}\text { South Asian } \\
(n=1,653)\end{array}$ \\
\hline Male, \% & 50.4 & 52.5 & 54.1 & 53.4 \\
\hline Mean age, y & 59.1 & 59.7 & 60.4 & 58.1 \\
\hline Comorbidity: 0, \% & 31.8 & 29.6 & 28.6 & 34.7 \\
\hline Comorbidity: $1, \%$ & 36.6 & 35.2 & 45.0 & 32.8 \\
\hline Comorbidity: $\geq 2, \%$ & 31.4 & 35.1 & 26.3 & 32.4 \\
\hline $\begin{array}{l}\text { Mean socioeconomic } \\
\text { score }^{a}\end{array}$ & 20.7 & 20.9 & 21.3 & 19.7 \\
\hline
\end{tabular}

Table 2. Interrupted Time Series Analysis for Mean Hemoglobin $A_{1 c}$ Levels

\begin{tabular}{|c|c|c|c|c|}
\hline \multirow[b]{2}{*}{ Parameter } & \multicolumn{4}{|c|}{$\mathrm{HbA}_{1 \mathrm{c}}, \%(95 \% \mathrm{Cl})$} \\
\hline & All Patients & White & Black & South Asian \\
\hline $\begin{array}{l}\text { Pre-QOF } \\
\text { trend }\end{array}$ & $\begin{array}{c}-0.21 \\
(-0.23 \text { to }-0.18)^{\mathrm{a}}\end{array}$ & $\begin{array}{c}-0.20 \\
(-0.24 \text { to }-0.17)^{\mathrm{a}}\end{array}$ & $\begin{array}{c}-0.21 \\
(-0.27 \text { to }-0.15)^{\mathrm{a}}\end{array}$ & $\begin{array}{c}-0.20 \\
(-0.26 \text { to }-0.15)^{\mathrm{a}}\end{array}$ \\
\hline $\begin{array}{c}\text { Level change } \\
\text { post-QOF }\end{array}$ & $\begin{array}{c}0.04 \\
(-0.04 \text { to } 0.12)\end{array}$ & $\begin{array}{c}0.07 \\
(-0.04 \text { to } 0.18)\end{array}$ & $\begin{array}{c}-0.12 \\
(-0.29 \text { to } 0.04)\end{array}$ & $\begin{array}{c}0.18 \\
(0.02 \text { to } 0.34)^{b}\end{array}$ \\
\hline $\begin{array}{l}\text { Post-QOF } \\
\text { trend }\end{array}$ & $\begin{array}{c}0.19 \\
(0.15 \text { to } 0.22)^{\mathrm{a}}\end{array}$ & $\begin{array}{c}0.21 \\
(0.16 \text { to } 0.26)^{\mathrm{a}}\end{array}$ & $\begin{array}{c}0.21 \\
(0.14 \text { to } 0.29)^{\mathrm{a}}\end{array}$ & $\begin{array}{c}0.11 \\
(0.04 \text { to } 0.18)^{\mathrm{a}}\end{array}$ \\
\hline $\begin{array}{l}\mathrm{HbA}_{1 \mathrm{c}}=\text { hemogl } \\
\text { a } P<.01 . \\
\text { b } P<.05 .\end{array}$ & ; QOF = Quality & Outcomes Framework. & & \\
\hline
\end{tabular}

$(P<.01)$. In its initial year, $Q \mathrm{OF}$ was associated with significant additional reductions in cholesterol levels in white and black patients, but not in South Asian patients $\left(-0.07 \mathrm{mmol} / \mathrm{L}_{i} 95 \% \mathrm{CI},-0.20\right.$ to $\left.0.04 \mathrm{mmol} / \mathrm{L}\right)$. During the next 3 years, the trend for mean cholesterol levels remained unchanged in black and South Asian patients but increased significantly in the white patients relative to the pre-QOF trend $(0.04 \mathrm{mmol} / \mathrm{L} ; 95 \% \mathrm{CI}, 0.01$ to $0.08 \mathrm{mmol} / \mathrm{L}$ ) (Table 3 and Figure 1).

\section{Blood Pressure}

Mean systolic blood pressure was decreasing in white patients $(-0.50 \mathrm{~mm} \mathrm{Hg}$; $95 \% \mathrm{CI},-0.93$ to $-0.08 \mathrm{~mm}$ $\mathrm{Hg})$ but not in black $\left(0.31 \mathrm{~mm} \mathrm{Hg}_{i} 95 \% \mathrm{CI},-0.20\right.$ to $0.83 \mathrm{~mm} \mathrm{Hg}$ ) or South Asian patients $(0.42 \mathrm{~mm} \mathrm{Hg}$; $95 \% \mathrm{CI},-0.16$ to $1.01 \mathrm{~mm} \mathrm{Hg}$ ) before introduction of the QOF program. In its initial year, QOF was associated with additional reductions in systolic blood pressure control in white $\left(-2.12 \mathrm{~mm} \mathrm{Hg}_{i} 95 \% \mathrm{CI},-3.48\right.$ to $-0.77 \mathrm{~mm} \mathrm{Hg})$ and black $(-2.32 \mathrm{~mm} \mathrm{Hg}$; $95 \% \mathrm{CI}$, -4.03 to $-0.61 \mathrm{~mm} \mathrm{Hg}$ ) patients but not in South Asian patients $(-1.08 \mathrm{~mm} \mathrm{Hg}$; $95 \% \mathrm{CI},-2.97$ to 0.08 $\mathrm{mm} \mathrm{Hg}$ ). During the next 3 years, there were significant additional reductions in mean systolic blood pressure in black $(-1.68 \mathrm{~mm} \mathrm{Hg}$; $95 \%$ CI to $-2.41,-0.95$ $\mathrm{mm} \mathrm{Hg}$ ) and South Asian patients $(-1.79 \mathrm{~mm} \mathrm{Hg}$; $95 \%$ $\mathrm{CI},-2.60$ to $-0.98 \mathrm{~mm} \mathrm{Hg})$, but not in white patients relative to the pre-QOF trend (Table 4 and Figure 1).

Mean diastolic blood pressure was decreasing in all 3 ethnic groups before introduction of the QOF program $(P$ $<.01)$. In its initial year, QOF was associated with additional reductions in diastolic blood pressure levels in white patients $(-1.01 \mathrm{~mm} \mathrm{Hg}$; 95\% CI, -1.79 to- $-0.24 \mathrm{~mm} \mathrm{Hg}$ ) but not in black or South Asian patients. During the next 3 years, mean diastolic blood pressures remained unchanged in all ethnic groups relative to the preQOF trend (Table 5 and Figure 1). Findings from our sensitivity analysis (Supplemental Appendix 1, available at http:// www.annfammed.org/content/10/3/228/suppl/DC1), were similar to those from our main analysis and suggest that they are robust (Supplemental 
Figure 1. Trends in mean hemoglobin $A_{1,}$, total cholesterol, and blood pressure levels.
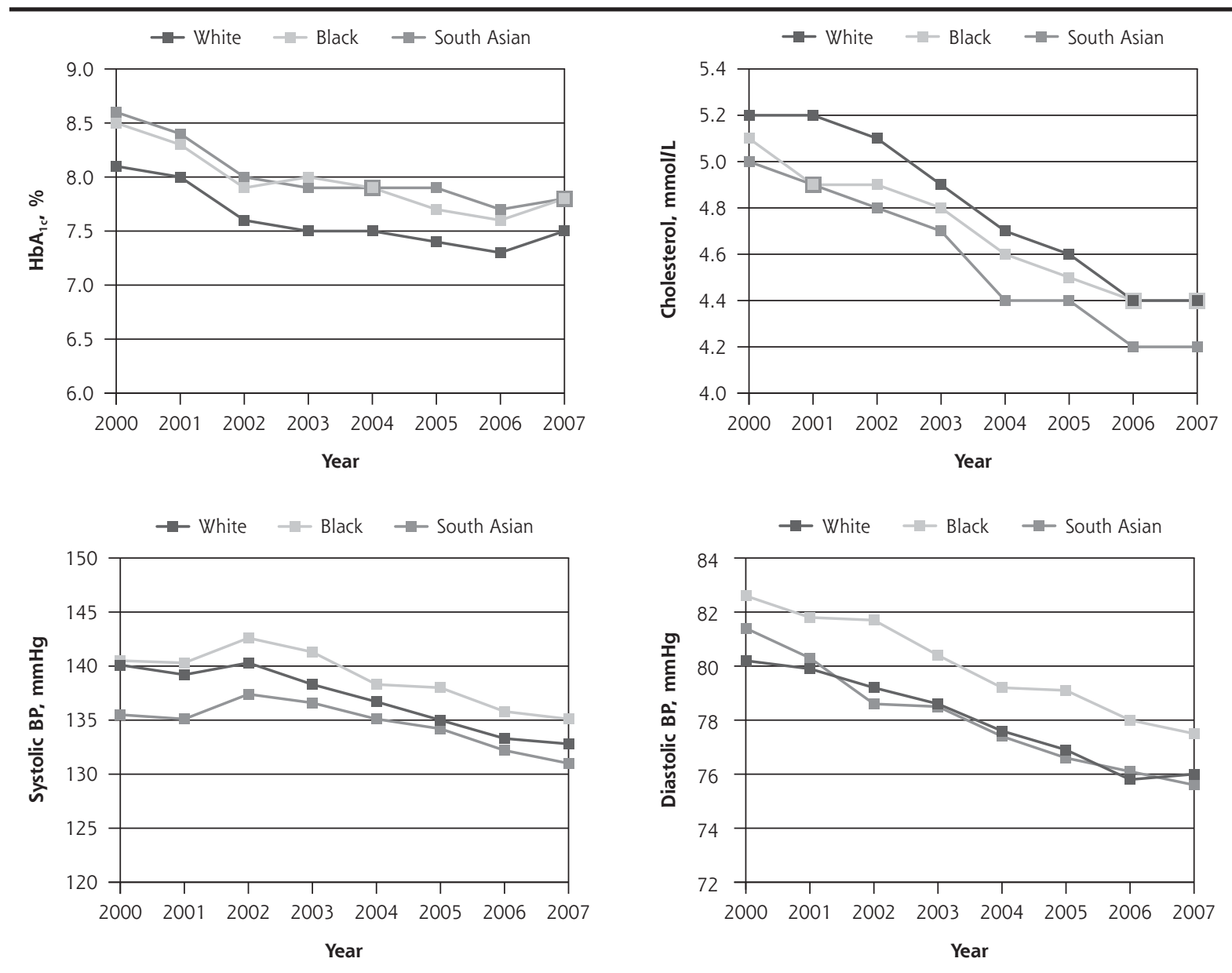

$\mathrm{BP}=$ blood pressure; $\mathrm{HbA}_{1 \mathrm{c}}=$ hemoglobin $\mathrm{A}_{1 \mathrm{c}}$ QOF $=$ Quality and Outcomes Framework

Note: Pre-QOF spanned 2000-2003, QOF introduced in 2004, post-QOF spanned 2005-2007.

Tables 1 and 2, available at http://www.annfammed.org/content/10/3/228/suppl/DC1).

\section{Overall Disparities Trend in Risk Factor Control}

Throughout the study period black patients had higher mean $\mathrm{HbA}_{\mathrm{ic}}$ levels and systolic and diastolic blood pressure when compared with the white group. Black patients continued to have significantly higher $\mathrm{HbA}_{1 \mathrm{c}}$ levels, and systolic and diastolic blood pressure before and after QOF compared with white patients. Similarly, throughout the study period South Asian patients had higher $\mathrm{HbA}_{1 \mathrm{c}}$ levels but lower systolic and diastolic blood pressures when compared with the white group. At the end of study South Asian patients continued to have higher levels of $\mathrm{HbA}_{\mathrm{lc}}$ when compared with white patients. Both black and South Asian patients had lower cholesterol levels when compared with the white group.

\begin{tabular}{|c|c|c|c|c|}
\hline \multirow[b]{2}{*}{ Parameter } & \multicolumn{4}{|c|}{ Cholesterol, $\mathrm{mmol} / \mathrm{L}(95 \% \mathrm{Cl})$} \\
\hline & All Patients & White & Black & South Asian \\
\hline $\begin{array}{l}\text { Pre-QOF } \\
\text { trend }\end{array}$ & $\begin{array}{c}-0.13 \\
(-0.15 \text { to }-0.11)^{\mathrm{a}}\end{array}$ & $\begin{array}{c}-0.15 \\
(-0.17 \text { to }-0.12)^{\mathrm{a}}\end{array}$ & $\begin{array}{c}-0.11 \\
(-0.14 \text { to }-0.08)^{\mathrm{a}}\end{array}$ & $\begin{array}{c}-0.13 \\
(-0.17 \text { to }-0.08)^{a}\end{array}$ \\
\hline $\begin{array}{l}\text { Level change } \\
\text { post-QOF }\end{array}$ & $\begin{array}{c}-0.12 \\
(-0.18 \text { to }-0.06)^{\mathrm{a}}\end{array}$ & $\begin{array}{c}-0.13 \\
(-0.21 \text { to }-0.05)^{\mathrm{a}}\end{array}$ & $\begin{array}{c}-0.10 \\
(-0.20 \text { to }-0.01)^{b}\end{array}$ & $\begin{array}{c}-0.07 \\
(-0.20 \text { to } 0.04)\end{array}$ \\
\hline $\begin{array}{l}\text { Post-QOF } \\
\text { trend }\end{array}$ & $\begin{array}{c}0.03 \\
(0.01 \text { to } 0.05)^{b}\end{array}$ & $\begin{array}{c}0.04 \\
(0.01 \text { to } 0.08)^{b}\end{array}$ & $\begin{array}{c}0.03 \\
(-0.01 \text { to } 0.07)\end{array}$ & $\begin{array}{c}0.02 \\
(-0.03 \text { to } 0.07)\end{array}$ \\
\hline $\begin{array}{l}\text { QOF }=\text { Quality ar } \\
\text { a } P<.01 . \\
\text { b } P<.05 .\end{array}$ & Dutcomes Framework. & & & \\
\hline
\end{tabular}




\section{DISCUSSION}

As in previous research on the quality of care delivered to diabetes patients in the United Kingdom before the introduction of QOF, ${ }^{17}$ our analysis indicates an underlying trend of general improvements in $\mathrm{HbA}_{1 \mathrm{c}}$, cholesterol, and blood pressure control predating QOF. The introduction of this pay-for-performance scheme appeared to have only a modest impact on some intermediate outcomes; it was associated with initial accelerated improvements in systolic blood pressure in white and black patients, but these improvements were sustained only in black patients. Initial improvements in diastolic blood pressure in white patients and in cholesterol level in black and white patients were not sustained in the post-QOF period. There was no beneficial impact of QOF on $\mathrm{HbA}_{1 \mathrm{c}}$ levels in any ethnic group. Existing disparities in risk factor control remained largely intact at the end of the study period.

Our findings that QOF had no significant effect on mean $\mathrm{HbA}_{1 \mathrm{c}}$ levels (they actually increased slightly during the post-QOF years) is in keeping with previous findings. ${ }^{18}$ Campbell et al, ${ }^{19}$ found significant change in the level of performance for diabetes care associated with QOF introduction; however, it is difficult to compare it with our findings, as they performed their analysis using a summary indicator rather than individual indicators. Furthermore, their analysis used practice-level data and did not adjust for various patient-level covariates. Calvert et al found a small improvement in the $\mathrm{HbA}_{1 \mathrm{c}}$ target level of $\leq 7.5 \%$ and no improvement was evident for a target level of $\leq 10 \%$. The authors, however, did not use a segmented time series analysis. ${ }^{20}$

Few studies have evaluated the impact of pay-for-performance programs on ethnic group disparities in health care. We have previously shown that the introduction of QOF was associated with increased disparities in risk factor control. ${ }^{10}$ The present study adds to this research by examining the longer term impact of this pay-for-performance program on the quality of diabetes management using a segmented time series methodology.

Our study has a number of strengths and limitations. The QOF was implemented nationally, which meant we did not have control over the introduction of the intervention, and as such, we could not use a randomized controlled trial to evaluate its impact. Nevertheless, the interrupted time series used is a robust quasi-experimental method that can withstand many biases and is superior to before-after study designs that do not take underlying trends into account. ${ }^{21}$ Further, as QOF was the only major quality improvement initiative introduced in primary care during 2004, it is
Table 4. Interrupted Time Series Analysis for Mean Systolic and Diastolic Blood Pressure

\begin{tabular}{|c|c|c|c|c|}
\hline \multirow[b]{2}{*}{ Parameter } & \multicolumn{4}{|c|}{ Blood Pressure, mm Hg $(95 \% \mathrm{Cl})$} \\
\hline & All Patients & White & Black & South Asian \\
\hline \multicolumn{5}{|l|}{ Systolic } \\
\hline $\begin{array}{l}\text { Pre-QOF } \\
\text { trend }\end{array}$ & $\begin{array}{c}-0.03 \\
(-0.31 \text { to } 0.25)\end{array}$ & $\begin{array}{c}-0.50 \\
(-0.93 \text { to }-0.08)^{\mathrm{a}}\end{array}$ & $\begin{array}{c}0.31 \\
(-0.20 \text { to } 0.83)\end{array}$ & $\begin{array}{c}0.42 \\
(-0.16 \text { to } 1.01)\end{array}$ \\
\hline $\begin{array}{l}\text { Level change } \\
\text { post-QOF }\end{array}$ & $\begin{array}{c}-1.95 \\
(-2.87 \text { to }-1.02)^{b}\end{array}$ & $\begin{array}{c}-2.12 \\
(-3.48 \text { to }-0.77)^{b}\end{array}$ & $\begin{array}{c}-2.32 \\
(-4.03 \text { to }-0.61)^{b}\end{array}$ & $\begin{array}{c}-1.08 \\
(-2.97 \text { to } 0.08)\end{array}$ \\
\hline $\begin{array}{l}\text { Post-QOF } \\
\text { trend }\end{array}$ & $\begin{array}{c}-1.04 \\
(-1.42 \text { to }-0.64)^{b}\end{array}$ & $\begin{array}{c}-0.21 \\
(-0.80 \text { to } 0.37)\end{array}$ & $\begin{array}{c}-1.68 \\
(-2.41 \text { to }-0.95)^{b}\end{array}$ & $\begin{array}{c}-1.79 \\
(-2.60 \text { to }-0.98)^{b}\end{array}$ \\
\hline \multicolumn{5}{|l|}{ Diastolic } \\
\hline $\begin{array}{l}\text { Pre-QOF } \\
\text { trend }\end{array}$ & $\begin{array}{c}-0.84 \\
(-1.00 \text { to }-0.67)^{\mathrm{b}}\end{array}$ & $\begin{array}{c}-0.69 \\
(-0.93 \text { to }-0.44)^{b}\end{array}$ & $\begin{array}{c}-0.84 \\
(-1.14 \text { to }-0.54)^{b}\end{array}$ & $\begin{array}{c}-1.06 \\
(-1.41 \text { to }-0.72)^{\mathrm{b}}\end{array}$ \\
\hline $\begin{array}{l}\text { Level change } \\
\text { post-QOF }\end{array}$ & $\begin{array}{c}-0.51 \\
(-1.05 \text { to } 0.01)\end{array}$ & $\begin{array}{c}-1.01 \\
(-1.79 \text { to }-0.24)^{\mathrm{a}}\end{array}$ & $\begin{array}{c}-0.33 \\
(-1.32 \text { to } 0.65)\end{array}$ & $\begin{array}{c}0.20 \\
(-0.90 \text { to } 1.30)\end{array}$ \\
\hline $\begin{array}{l}\text { Post-QOF } \\
\text { trend }\end{array}$ & $\begin{array}{c}0.19 \\
(-0.03 \text { to } 0.41)\end{array}$ & $\begin{array}{c}0.10 \\
(-0.23 \text { to } 0.43)\end{array}$ & $\begin{array}{c}0.12 \\
(-0.30 \text { to } 0.54)\end{array}$ & $\begin{array}{c}0.40 \\
(-0.07 \text { to } 0.87)\end{array}$ \\
\hline \multicolumn{5}{|c|}{$\mathrm{QOF}=$ Quality and Outcomes Framework. } \\
\hline \multicolumn{5}{|l|}{ a $P<.05$} \\
\hline
\end{tabular}

Table 5. Ethnic Differences in Mean Risk Factor Levels Before and After QOF and Pooled 8-Year Differences From 2000 to 2007

\begin{tabular}{|c|c|c|c|c|c|c|}
\hline \multirow[b]{2}{*}{ Ethnic Group } & \multicolumn{3}{|c|}{$\begin{array}{c}\mathrm{HbA}_{1 \mathrm{c}} \\
\%(95 \% \mathrm{Cl})\end{array}$} & \multicolumn{3}{|c|}{$\begin{array}{c}\text { Cholesterol } \\
\mathrm{mmol} / \mathrm{L}(95 \% \mathrm{Cl})\end{array}$} \\
\hline & 2003 & 2007 & Difference & 2003 & 2007 & Difference \\
\hline White & 7.5 & 7.5 & $\begin{array}{c}-0.04 \\
(-0.15 \text { to } 0.06)\end{array}$ & 4.9 & 4.4 & $\begin{array}{c}-0.47 \\
(-0.54 \text { to }-0.39)\end{array}$ \\
\hline Black & $8.0^{a}$ & $7.8^{\mathrm{a}}$ & $\begin{array}{c}-0.18 \\
(-0.35 \text { to }-0.02)\end{array}$ & $4.8^{a}$ & 4.4 & $\begin{array}{c}-0.38 \\
(-0.47 \text { to }-0.29)\end{array}$ \\
\hline South Asian & $7.9^{a}$ & $7.8^{\mathrm{a}}$ & $\begin{array}{c}-0.17 \\
(-0.32 \text { to }-0.02)\end{array}$ & $4.7^{\mathrm{a}}$ & $4.2^{\mathrm{a}}$ & $\begin{array}{c}-0.47 \\
(-0.58 \text { to }-0.35)\end{array}$ \\
\hline
\end{tabular}

$\mathrm{HbA}_{1 \mathrm{c}}=$ hemoglobin $\mathrm{A}_{1 c i} \mathrm{QOF}=$ Quality and Outcomes Framework.

${ }^{a}$ Indicates significant differences to white group at $5 \%$ level after adjusting for age, sex, socioeconomic status, number of comorbidities, and practice-level clustering. 
reasonable to attribute any additional improvements in diabetes management seen to this policy. Changes in our population during the study period could have affected our estimate, but such bias would be limited because we used individual-level, longitudinal data on patients. Our study is based on retrospective data from patients registered with practices in 2007, which means that we do not have information on patients who died or changed their practice during the study period.

Our sensitivity analyses, which accounted for the possibility of attrition bias, yielded results substantiating the robustness of findings from our main analysis.

Because there were only a few patients in some of the ethnic groups, we had to combine patients into 3 main groups. We accept that such grouping might mask differences in diabetes management. ${ }^{22}$ We were not able to distinguish between patients with type 1 and type 2 diabetes. Our findings were derived from one primary care organization in the United Kingdom and may not reflect the impact of QOF in other parts of the country or be transferable to pay-for-performance programs in other health systems. Finally, we used practice-based postal codes to assign deprivation scores to patients, which may not present a true estimation of their individual socioeconomic position.

Our findings suggest that this major pay-forperformance program has not addressed important disparities in chronic disease management in its first 3 years; that is, the findings are thus far not consistent with the inverse equity hypothesis that disparities will be reduced over time. Our findings do provide support for the view that targeted quality improvement strategies may be required to address disparities in chronic disease management. Designers of pay for performance should weigh the effect of such schemes on minority patients and consider incorporating targeted incentives to address the persistence of such disparities. Local efforts in the United Kingdom to reduce disparities by using financial incentives to improve care in minority groups and monitor progress through better recording of ethnicity and first language may represent a promising step forward. ${ }^{23}$

To read or post commentaries in response to this article, see it online at http://www.annfammed.org/content/10/3/228.

Key words: pay for performance; disparities; diabetes

Submitted March 18, 2011; submitted, revised, August 3, 2011; accepted September 6, 2011.

Author contributions: Riyadh Alshamsan had full access to all of the data in the study and takes responsibility for the integrity of the data and the accuracy of the data analysis.

Funding support: This study represents independent research commissioned by the National Institute for Health Research (NIHR) Service Delivery \& Organization program (08/1716/209). The Wandsworth Primary Care Research Centre has received funding from the Department of Health. Department of Primary Care $\&$ Public Health at Imperial College London received support from the NIHR Biomedical Research Centre scheme; the NIHR Collaboration for Leadership in Applied Health Research \& Care scheme, and the Imperial Centre for Patient Safety and Service Quality. Dr Netuveli is supported by ESRC International Centre for Life Course Studies in Society and Health (RES -596-28-0001).

Disclaimer: The views expressed in this publication are those of the authors and not necessarily those of the National Health Service, the National Institute for Health Research, or the Department of Health.

\section{References}

1. Millett C, Gray J, Saxena S, Netuveli G, Khunti K, Majeed A. Ethnic disparities in diabetes management and pay-for-performance in the UK: the Wandsworth Prospective Diabetes Study. PLoS Med. 2007;4(6):e191.

2. Chien AT, Chin MH, Davis AM, Casalino LP. Pay for performance, public reporting, and racial disparities in health care: how are programs being designed? Med Care Res Rev. 2007;64(5)(Suppl): 2835-304S.

3. Werner RM, Asch DA, Polsky D. Racial profiling: the unintended consequences of coronary artery bypass graft report cards. Circulation. 2005;111(10):1257-1263.

4. Alshamsan R, Majeed A, Ashworth M, Car J, Millett C. Impact of pay for performance on inequalities in health care: systematic review. J Health Serv Res Policy. 2010;15(3):178-184.

5. Van Herck P, De Smedt D, Annemans L, Remmen R, Rosenthal $M B$, Sermeus W. Systematic review: Effects, design choices, and context of pay-for-performance in health care. BMC Health Serv Res. 2010;(Aug):10.

6. Victora CG, Vaughan JP, Barros FC, Silva AC, Tomasi E. Explaining trends in inequities: evidence from Brazilian child health studies. Lancet. 2000;356(9235):1093-1098.

7. Ho K, Moy E, Clancy CM. Can incentives to improve quality reduce disparities? Health Serv Res. 2010;45(1):1-5.

8. Department of Health. The NHS Improvement Plan: Putting People at the Heart of Public Services. London: Department of Health; 2004.

9. World Health Organization. Closing the Gap in a Generation: Health Equity through Action on the Social Determinants of Health. Final Report of the Commission on Social Determinants of Health. Switzerland, Geneva: World Health Organization; 2008. 
10. Millett C, Netuveli G, Saxena S, Majeed A. Impact of pay for performance on ethnic disparities in intermediate outcomes for diabetes: a longitudinal study. Diabetes Care. 2009;32(3):404-409.

11. Gray J, Orr D, Majeed A. Use of Read codes in diabetes management in a south London primary care group: implications for establishing disease registers. BMJ. 2003;326(7399):1130.

12. Majeed A. Sources, uses, strengths and limitations of data collected in primary care in England. Health Stat Q. 2004;(21):5-14.

13. Department of Communities and Local Government. Indices of Deprivation 2007. http://webarchive.nationalarchives.gov.uk/+/com munities.gov.uk/communities/neighbourhoodrenewal/deprivation/ deprivation07/. Accessed Dec 12, 2010.

14. Eccles M, Grimshaw J, Campbell M, Ramsay C. Research designs for studies evaluating the effectiveness of change and improvement strategies. Qual Saf Health Care. 2003;12(1):47-52.

15. Wagner AK, Soumerai SB, Zhang F, Ross-Degnan D. Segmented regression analysis of interrupted time series studies in medication use research. J Clin Pharm Ther. 2002;27(4):299-309.

16. Heckman JJ. Sample Selection Bias as a Specification Error. Econometrica. 1979;47(1):153-161.

17. Lusignan S, Sismanidis C, Carey IM, DeWilde S, Richards N, Cook DG. Trends in the prevalence and management of diagnosed type 2 diabetes 1994-2001 in England and Wales. BMC Fam Pract. 2005; 6(1):13.
18. Millett C, Bottle A, Ng A, et al. Pay for perfomance and the quality of diabetes management in individuals with and without co-morbid medical conditions. J R Soc Med. 2009;102(9):369-377.

19. Campbell SM, Reeves D, Kontopantelis E, Sibbald B, Roland M. Effects of pay for performance on the quality of primary care in England. N Engl J Med. 2009;361(4):368-378.

20. Calvert M, Shankar A, McManus RJ, Lester H, Freemantle N. Effect of the quality and outcomes framework on diabetes care in the United Kingdom: retrospective cohort study. BMJ. 2009;338:b1870.

21. Biglan A, Ary D, Wagenaar AC. The value of interrupted time-series experiments for community intervention research. Prev Sci Mar. 2000;1(1):31-49.

22. Bhopal R, Unwin N, White M, et al. Heterogeneity of coronary heart disease risk factors in Indian, Pakistani, Bangladeshi, and European origin populations: cross sectional study. BMJ. 1999;319 (7204):215-220.

23. Millett C, Majeed A, Huckvale C, Car J. Going local: devolving national pay for performance programmes. BMJ. 2011;342:c7085.

\section{CHANGE-OF-ADDRESS FORM FANMILY MEDICINE"}

Please complete this form and mail to the following address or fax to Annals Circulation at 913-906-6080:

Annals of Family Medicine, Circulation Department, 11400 Tomahawk Creek Pkwy, Leawood, KS 66211-2680

Check if member of sponsoring organization: $\square$ AAFP $\square$ ABFM $\square$ STFM $\square$ ADFM

$\square$ AFMRD $\square$ NAPCRG $\square$ CFPC

ID number from label on your journal cover

OLD Information (Please print.)

Name

Company (if applicable)

Address (Street plus Apt or Ste)

City

Country

Postal Code (9-digit ZIP for US)

Telephone

Fax

E-Mail
NEW Information (Please print.)

\begin{tabular}{ll}
\hline Name \\
\hline Company (if applicable) & \\
\hline Address (Street plus Apt or Ste) & State \\
\hline City & Postal Code (9-digit ZIP for US) \\
\hline Country & Fax \\
\hline Telephone & \\
\hline E-Mail
\end{tabular}

